\title{
Undergraduate business education students' perception on information and communication technology use in teaching and learning
}

\author{
Patrick Uzo Osadebe ${ }^{1}$, Joyce Frances Osadebe ${ }^{2}$ \\ ${ }^{1}$ Department of Guidance and Counselling, Delta State University, Nigeria \\ ${ }^{2}$ Delta State Basic and Secondary Education, Nigeria
}

\begin{tabular}{l} 
Article Info \\
\hline Article history: \\
Received Sep 12, 2019 \\
Revised Feb 19, 2020 \\
Accepted Apr 30, 2020 \\
\hline
\end{tabular}

Keywords:

Assessment

Education

Perception

Teaching and learning

\begin{abstract}
The study was carried out to assess the undergraduate Business Education Students' Perception on the use of Information and communication technology (ICT) in teaching and learning in the University. Thus, to achieve the purpose, two research questions and two hypotheses guided the study. A sample of 100 students was randomly drawn using balloting and proportionate stratified random sampling techniques. A questionnaire of 4-point scale was used to collect data. It has face validity determined through expert judgement, and construct validity verified through factor analysis. The reliability of the instrument was obtained through Cronbach Alpha. A reliability coefficient of 0.82 was obtained as a measure of internal consistency. The data collected were analyzed with mean and Z-test. Mean was used to answer the research questions while Z-test was used to test the hypotheses at the 0.05 level of significance. The result showed that there was high perception of students to use ICT in teaching and learning in the university. There was no significant difference between male and female students as well as 300 level and 400 level students on the use of ICT in teaching and learning. Therefore, it was recommended that ICT should be used in teaching and learning Business Education in the University.
\end{abstract}

This is an open access article under the CC BY-SA license.

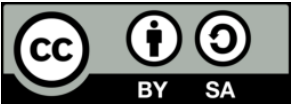

\footnotetext{
Corresponding Author:

Patrick Uzo Osadebe,

Department of Guidance and Counselling,

Delta State University,

Abraka, Nigeria.

Email: drosadebeuzo@gmail.com
}

\section{INTRODUCTION}

The use of Information and Communication Technology (ICT) in teaching students would help to improve their learning of Business Education in the University. However, this depends on their perception in the use as in the case of this study. The ICT has not been fully used in teaching and learning in Nigerian Universities. Business Education is a subject area in the University that requires the use of ICT in teaching and learning. Some of the facilities used in ICT are already being used in a similar way in Business Education such as keyboard to computer as related to typewriter used in Business Education. It has been defined that information and Communication Technology is a scientific method of disseminating information within the quickest possible time [1]. It involves the use of computer and other accessories in providing information. These would serve as good aids for teaching and learning. The Wikipedia [2] has pointed that ICT could be used in the teaching and learning of a subject matter that enables a learner to understand the functions and its effective use. This implies that ICT facilities could be used to teach Business Education. 
One of the greatest problems in Nigeria is that the undergraduate students in Business Education are used to the old method of providing information. These include typewriter, telegram, post office which takes long time to deliver its message. All these problems called for the use of ICT which facilitates messages in the shortest time [3]. Therefore, the perception of the undergraduate Business Education students should be assessed on the use of ICT in teaching and learning. Knowledge of the students' perception would help to facilitate the application of ICT in teaching and learning. Generally, students' perception may not be the same. It could be high or low. Male students' perception may differ or not from female. The same may apply to rural and urban students. All that is required is to guide the students during the use of ICT in teaching and learning in the classroom.

Information and Communication Technology could be used for different purposes. In teaching and learning, computer, projector, Television and other visual and audio-visual aids connected to the internet or ICT centre could be used to teach students and monitor their learning progress. Software could also be provided. ICT could be utilized to improve efficiency, effectiveness and excellence in teaching and learning. Students could be taught from a distant through the ICT centre to the classrooms where they receive lectures. Students would have the opportunity to see and listen to the teacher. A television screen could be used to provide video and audio visual aid during the teaching period. Webcam in laptops could also be used to facilitate teaching and learning. The students will have the opportunity to ask questions and interact. All these would help to improve teaching and learning with ICT in Business Education.

Another advantage of ICT is the use of website for learning. Students could obtain information from the website about their subject areas as well as do their assignment [4]. ICT has a lot of advantages to teaching and learning. The perception of students would help them to improve when ICT is properly applied to teaching and learning. However, the greatest problems to ICT are power and network to ICT failures. There should be constant power supply and stable network. It has been pointed out that information and Communication Technology (ICT) is the use of scientific method to provide and receive information faster and better [5, 6]. Many scholars and organizations have supported the use of ICT. These include [7, 8]. ICT in education refers to the teaching and learning with ICT tools. This should be applied to Business Education to improve teaching and learning. ICT serves as a tool, as an agent of change, and as an alternative measure. The use of telephone, websites, e-mail, face to face facilities could be alternative services [9].

In education, ICT tools could be divided into three categories. These include input source, output source and others. The input source includes: Visualize Document camera, personal computers, slate, software and students' response system. The output includes: projector, interactive whiteboard, monitor and TV. Other tools include Digital switcher, and Digital recorder. ICT leads to improved students learning and better teaching methods. It has positive impact on students' achievement especially in Business Education in terms of knowledge, comprehension and practical skills. Thus, through ICT, images can easily be used in teaching and improving the retentive memory of students. Teachers can easily explain complex instructions and ensure students' comprehension. Furthermore, teachers are able to create interactive classes and lessons more interesting which could improve students' attendance and individual concentration. Therefore, with ICT, it is easy to see that visualize or so called document camera can be the most effective and efficient ICT tool for education. The visualize or document camera is a digital teaching tool that will allow a teacher and students to display and share much wider range of information to the class and bring lectures or lessons to life.

Assessment of students focuses on the cognitive, affective, and psychomotor domains of Behaviour [10]. The Federal Government of Nigeria [11-13] recommended assessment of students in schools. This was also recommended by [14] on continuous assessment. Cognitive behavior is concern with students' ability to think and reason. It deals with the mental process [15-19]. Assessment of students' perception as it is in this study is related to the affective behaviour [20,21]. Perception determines students feeling or the way they see issues related to their life. Therefore, the use of ICT in teaching and learning is an important issue in the life of students towards their education [22]. Psychomotor behavior deals with students' skills. That is ability to write, read, speak, and draw among others [23, 24]. Assessment of students' perception is necessary because it helps to determine how students see and feel about the use of ICT in teaching and learning of Business Education in the university. It has been defined that assessment is the use of valid and reliable instruments or techniques such as test, observation, questionnaire, interview among others in obtaining information about students' behaviour upon which judgement is made [25]. The focus of assessment is to analyze information provided by test, interview, questionnaire, observation among others and to combine the data to make complex and important judgement about individual [26-29]. Assessment would help to determine whether students' perception is low or high on the use of ICT in teaching and learning. Therefore, the problem of this study if put in question form is: What is the perception of Business Education undergraduate students on the use of ICT in teaching and learning? The main purpose of the study was to assess the perception of undergraduate Business Education students on the use of ICT in teaching and learning in University.

Int. J. Eval. \& Res. Educ. Vol. 9, No. 2, June 2020: 359 - 363 
Specifically, the study: (i) assess the perception of male and female undergraduate Business Education students on the use of ICT in teaching and learning; (ii) assess the perception of 300 level and 400 level undergraduate Business Education students on the use of ICT in teaching and learning.

\section{RESEARCH METHOD}

The study assessed the perception of undergraduate Business Education students on the use of ICT in teaching and learning in the University. The dependent variable is perception. The independent variables include the sex and class level of students. Thus, the perception on the use of ICT for teaching and learning depends on the students' sex and class level.

Delta State University, Abraka was used as a case study. The population consists of 300 and 400 level students. They have taken courses related to ICT. A sample of 100 undergraduate Business Education students was randomly selected through simple random sampling of balloting and proportionate stratified random sampling techniques. The instrument used was a questionnaire of 4-point scale. The instrument has face validity obtained through expert judgement, and construct validity verified through factor analysis. Cronbach Alpha was used to determine the reliability. A reliability coefficient of 0.82 was obtained as measure of internal consistency.

The data collected were analyzed in line with the research questions and hypotheses. To answer each research question, a bench mark of 40 and above was considered as high perception. Then, a mark below 40 was considered as low perception. Each hypothesis was tested with Z-test at the 0.05 level of significance.

\section{RESULTS AND DISCUSSION}

3.1. Research question 1: What is the perception of male and female undergraduate business education students on the use of ICT in teaching and learning?

Table 1 shows that the mean perception of male students was 65.01 while that of female students was 63.22. The mean scores of both male and female were above the bench mean of 40 indicating high perception. Therefore, the result revealed high perception of male and female students on the use of ICT for teaching and learning in the University.

Table 1. Mean analysis of male and female undergraduate business education students' perception

\begin{tabular}{llll}
\multicolumn{4}{c}{ on the use of ICT in teaching and learning } \\
\hline Gender & $\mathrm{N}$ & Mean & Decision \\
\hline Male & 60 & 65.01 & High \\
Female & 40 & 63.22 & High
\end{tabular}

3.2. Research question 2: What is the perception of 300 level and 400 level undergraduate business education students on the use of ICT in teaching and learning?

Table 2 presents the mean score of the perception of 300 level and 400 level students on the use of ICT in teaching and learning. The mean score of 300 level students was 64.02 and 66.12 for the 400 level students. The mean scores of both 300 level and 400 level students were above the bench mark of 40 indicating high perception. Therefore, there was a high perception of 300 and 400 level students on the use of ICT in teaching and learning.

Table 2. Mean analysis of 300 level and 400 level undergraduate business education students' perception

\begin{tabular}{llll}
\multicolumn{4}{l}{ on the use of ICT in teaching and learning } \\
\hline Gender & $\mathrm{N}$ & Mean & Decision \\
\hline 300 level & 40 & 64.02 & High \\
400 level & 60 & 66.12 & High \\
\hline
\end{tabular}

3.3. Hypothesis one: There is no significant difference between the perception of male and female undergraduate business education students on the use of ICT in teaching and learning

Table 3 showed that the calculated Z-value of 0.95 was less than the critical Z-value of 1.96 at the 0.05 level of significance. The null hypothesis was accepted. The result maintains that there was no 
significant difference between the perception of male and female undergraduate Business Education students on the use of ICT in teaching and learning.

Table 3. Z-test analysis on the perception of male and female undergraduate business education students on the use of ICT in teaching and learning

\begin{tabular}{ccccccc}
\hline Gender & $\mathrm{N}$ & Mean & SD & Calculated Z-value & Critical Z-value at .05 & Decision \\
\hline Male & 60 & 65.01 & 7.33 & 0.95 & \multirow{2}{*}{1.96} & Accepted \\
Female & 40 & 63.22 & 6.02 & & & \\
\hline
\end{tabular}

3.4. Hypothesis two: There is no significant difference between the perception of 300 level and 400 level undergraduate business education students on the use of ICT in teaching and learning

Table 4 indicates that the calculated Z-value of 1.69 was less than the critical Z-value of 1.96 at the 0.05 level of significance. The null hypothesis was accepted. The result revealed that there was no significant difference between the perception of 300 level and 400 level undergraduate Business Education students on the use of ICT in teaching and learning.

Table 4. Z-test analysis on the perception of 300 level and 400 level undergraduate business education

\begin{tabular}{ccccccc}
\multicolumn{7}{c}{ students on the use of ICT in teaching and learning } \\
\hline Class level & $\mathrm{N}$ & Mean & SD & Calculated Z-value & Critical Z-value at .05 & Decision \\
\hline 300 level & 40 & 64.02 & 8.50 & 1.69 & 1.96 & \multirow{2}{*}{ Accepted } \\
400 level & 60 & 66.12 & 9.11 & 1.69 & &
\end{tabular}

The results revealed high perception of undergraduate Business Education students on the use of ICT in teaching and learning. The same applied to the perception of male and female as well as 300 and 400 level students. The results implied that students supported the use of ICT in teaching and learning Business Education in the University. The result also showed that there was no significant difference between the perception of male and female students as well as between 300 level and 400 level students on the use of ICT in the teaching and learning of Business Education in the University. The results supported the work of [30] who proposed that ICT should be used to assess Business Education students. This would help the students to be in line with current development. This includes change from analog to digital. Other scholars who supported the use of ICT in schools are in line with the findings of Kaka [31]. Wagner, Osadebe, and the Joint Admission [32-34] also supported the use of ICT for assessing Business Education students.

The results are at variance with the University policy in Nigeria where ICT is the old methods only taught to students for knowledge but do not practically use the facilities of ICT in teaching and learning. The old method is still being implemented. Computer based testing has not been fully introduced. The E-mail and website have not been fully used for students learning. However, the high perception of students has revealed that ICT facilities should be used in the teaching and learning of Business Education in the University.

\section{CONCLUSION}

The study assessed the perception of undergraduate Business Education students on the use of ICT in teaching and learning in the University. Currently, ICT tools are not being used to teach the students. These tools include internet connection, websites, visualiser, Document camera, computers, software, students' response system, projector, interactive white board, monitor, TV, switcher, digital recorder among others. The students need ICT tools to be well informed and learn better. The result of the study revealed that students' perception was high in favour to the use of ICT in teaching and learning. This implies that ICT should be used in teaching and learning in the University.

\section{REFERENCES}

[1] Osadebe, P U., "Assessment score of university lecturers," Journal of Education and Practice, vol. 5, no. 2, pp. 8-14, 2014.

[2] Wikipedia, "Information and communication technology," 2014. Retrieved on 5th April from free Encyclopedia. 
[3] Osadebe, P U., "Teachers assessment of classroom learning outcomes," Journal of Education and practice, vol. 5, no. 15, pp. 15-21, 2014.

[4] P. U. Osadebe, "Use of computer in Information and communication technology," A seminar Paper, Delta State University, Abraka, 2014.

[5] Wikipedia, "Information and communication technology use in teaching and learning," 2016. Retrieve on 10th October from free Encyclopedia.

[6] P.U. Osadebe, "Standardadizattion of test for assessment and comparing of students' measurement," International Education Studies, vol. 7, no. 5, pp. 94-103, 2014.

[7] P.U. Osadebe, "Evaluation of achievement of universal basic education in Delta state," Education, vol. 134, no. 3, pp. 419-424, 2014.

[8] Joint Admission and Matriculation Board, Computer based test e -registration, Abuja: JAMB printing press, 2014.

[9] N.D. Oye, M.C. Obi, T.N. Mohd, and A. Bernice, "Guidance and counseling in Nigeria secondary schools on the role of ICT," Journal of modern Education and computer science, vol. 8, pp 33-36, 2012.

[10] P.U. Osadebe, "Evaluation of continuous assessment practice by university lecturers," International Journal of Evaluation and Research in Education, vol. 4, no. 4, pp. 215-220, 2015.

[11] Federal Government of Nigeria, National policy on education. Lagos, Government Printing Press, 1981.

[12] Federal Government of Nigeria, National policy on education. Lagos. Government Printing Press, 1998.

[13] Federal Government of Nigeria, National policy on education. Nigeria Educational Research and Development Council Press, 2014.

[14] Federal Ministry if Education Science and Technology, A Handbook on continous Assessment. Ibadan Heine mann Educational Books Nigeria, Ltd., 1985.

[15] B.S. Bloom, Taxonomy of Educational objectives of cognitive Domain. New York. David Mc Kay Co. Inc., 1956.

[16] P.U. Osadebe, "Students Academic Ability in school-based Assessment as correlate of career choice," British Journal of Education, society and Behavioural Science, vol. 7, no. 2. pp. 150-156, 2015.

[17] R.P.I. Ukwuije, Test and Measurement. Port Harcourt. Abe Publishers, 1996.

[18] R.P.I. Ukwuije and G.W. Orluwene, Peanuts Educational Statistics. Port Harcourt. Chadik Printing Press, 2012.

[19] P.J. Kpolovie, Test Measurement and Evaluation. Port Harcourt, Emhai Printing and Publishing Co., 2002

[20] D.R. Krathwohl, Taxonomy of Affective Domain. New York. David Mc Kay., Inc., 1964.

[21] P.U. Osadebe, "Test item fairness for assessment of male and female students' achievement in Economics," International Journal of Current Advanced Research, vol.7, no. 5, pp. 12632-12636, 2018.

[22] P.U. Osadebe and T.O. Esegbue, "Evaluation of students' academic performance in JAMB Chemistry test under the computer based testing and paper pencil media in Delta State University," Int. J. of Adv. Res., vol. 6, no. 5, pp. 415-426, 2018.

[23] A.J.A. Harrow, Taxonomy of the Psychomotor Domain. New York, David Mc Kay Co., Inc., 1972.

[24] P.U. Osadebe, "Evaluation of undergraduate students' performance in Test and Measurement achievement test with sample from probabilistic and non-probabilistic sampling procedures," International Journal of Assessment and Evaluation in Education, vol. 7, no. 1, pp. 26-31. 2017.

[25] P.U. Osadebe, "Teachers' continuous assessment practice," A seminar paper, Delta State University, Abraka, 2013.

[26] L.W. Aiken, Psychological testing and assessment. Boston. Allyn and Bacon, Inc., 1979.

[27] N.E. Gronlund, Measurement and evaluation in teaching. New York Macmillian Publishing Co. Inc., 1985.

[28] K.R. Murphy and C.O. David shofer, Psychological testing. New Jersey, Prentice Hall International Inc., 1988.

[29] P. Eggen and D. Kauchak, Educational Psychology. New York, Macmillan Publishing Company, 1994.

[30] P.U. Osadebe, "Assessment of test items with Rasch Measurement Model," Journal of Applied Measurement, vol. 19, no. 1, pp. 106-112, 2018.

[31] S. Kaka, "The role of ICT in education Sector," 2014. [Online]. Available: http//verykaka.word press

[32] M.M. Wagner -Menghin and G.N. Master, "Adaptive Testing for Psychological Assessment," Journal of Applied Measurement, vol. 14, no. 2, pp. 106-117, 2013.

[33] P.U. Osadebe. "Assessment of students' perception on population control measures," British Journal of Advanced Academic Research, vol. 2, no. 1, pp. 95-103, 2013.

[34] Joint Admission and Matriculation Board, Computer Assessment. Abuja JAMB Printing Press, 2018. 